\title{
The Ontology of S.I. Taneev's Art
}

\author{
Galima Lukina \\ Russian State Specialized Academy of Arts \\ Moscow, Russia \\ E-mail: galimalukina@yandex.ru
}

\begin{abstract}
The article is devoted to the understanding of art by the Russian composer: S.I. Taneev. His music is treated as a special compositions philosophizing within sounds, consonant to Russian religious philosophy. The author believes that the leading idea of Taneev's art, formulated by the researchers as the "motion to the light", is based on the philosophical "foundation" of composer's native culture with its ideals of love, unity, philokalia, selfless devotion, theosis, etc.
\end{abstract}

Keywords-Sergey Taneyev; the ontology of art; Russian music; Russian religious-philosophical tradition

\section{INTRODUCTION}

Sergey Ivanovich Taneyev is a bright representative of Russian artistic culture of the last quarter of the 19th beginning of the 20th century. He is a composer and a thinker whose work is noted for conceptual depth and philosophical contemplation.

One would think this statement to be generally accepted and not demanding evidence. However, as soon as we try to understand what exactly is most accordant with Taneyev in the turn-of-the-century Russian culture, known as the Silver Age, the Third (Slavic) Renaissance, or the Cultural Renaissance, quite a number of questions arise. What sort of philosophical ideas and worldview beginnings lie at the basis of the music of Taneyev's cantatas St. John Damascene, At the Reading of a Psalm and the trilogy Oresteia. Are these ideas of Positivism, Marxism, Neoslavophilism or Spinozism?

Is it at all possible to talk about a certain philosophy of artistic work, philosophy of music, painting or literature of a given artist if there are no philosophical texts by the author (E.g. Schelling's Philosophy of Art or Losev's Music as a Subject of Logic)?

Indeed, philosophy is not explicitly evident in Taneyev's compositions, not in its purest form, like in the works by such acknowledged thinkers in art such as J. S. Bach, Michelangelo or F. M. Dostoyevsky. Yet, it's on the philosophical level of understanding that the depth of the contents of ideas nourishing the living fabric of their works reveals itself.

The latter appears possible on condition of connecting the analytical framework of methodology of art history (music history in this case) and methodology of philosophical ontology. It allows the analysis of the text as a whole, without destroying its ideology and anatomizing the work. The intonation and ontological level of understanding corresponds to the major subject of music philosophy - the intontation expressed Logos1. So, the matter in question is music as the language of ontology, of existence in all its dimensions with the priority of the spiritual one.

\section{LOVE IS THE LOGO IN TANEEV'S MusiC}

The argument in favor of the suggested approach is the fact that for Taneyev himself, art maximally activates the spiritual aspirations and formation of value hierarchy in the objective reality, where the absolute ideals are the eternal Christian ones.

Turning to Taneyev's compositions one can't but admit that the high moral tone is probably their most essential characteristic. Taneyev's whole creative work - from the first opus St. John Damascene to the last At the Reading of a Psalm - is permeated with the idea of never-dying love, possible only at 'a heart purer than gold'.

All lines of sacred, emotional, psychic and spiritual development of an individual join in the heart. That's why in Russian philosophy there are so many speculations about the heart which is the field of battle between Good and Evil and the place where there confrontation is solved. This is what Taneyev's trilogy, Oresteia, is about. Taneyev opens to us the core values of Russian culture: the evangelical understanding of the problems of sin, temptation and conscience. Taneyev's Orest, having gone his tragic way, experiences in the scene of forgiveness a truly Christian feeling of joy of a redeemed soul. In Taneyev's opera, Aeschylus's 'dialectic of kindred and individual in their tragic development when everyone is equally guilty and innocent' $[1,123]$ is opposed by the Orthodox Christian system of values in human spiritual life.

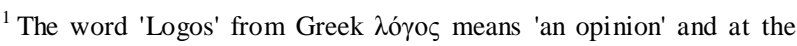
same time 'a ground', 'reason', that is to say the Logos is the source of thought. Consequently, the word 'ontology' literally denotes a source of thought about the creation.

In Russian culture, 'the Logos' is perceived in evangelical context: 'In the beginning was the Word, and the Word was with God, and the Word was God. Thus, the understanding is born that 'the source of the word in the world is the Holy Word' (S. N. Bulgakov, Philosophy of the Name, Saint Petersburg, 1998, p. 269), and the creative core of the existence is organized into the symbol of the Logos-Word (I. V. Yefimova, Logos and Melos, Krasnoyarsk, 2008, p. 5). It's characteristic that the originality of the church singing tradition of Ancient Rus' lies in the peculiarities of the interaction of the Logos and Melos.
} 
Exactly in this sense the lines that the final scene of Taneyev's Oresteia is based on should be read:

The one who with heartful penitence

And tears has laved one's sin,

Who has purified oneself with suffering,

Has deserved forgiveness.

...May from now on, not grudge,

Not an eye for an eye,

but love and gentleness be man's lot.

The idea of love for one's neighbors or, using the terminology of Russian philosophy, "sobornost" love, is the Logos of Taneev's music.

\section{INTONATIONAL EXPRESSION OF THE LOGO 3}

The analysis of both his choral and instrumental works proves the natural tie between Taneyev's musical language and the "Word". Thus, his peculiar method is accentuating a set speech intonation (question, pleading, exclamation, call, etc.) in the melody. Similar to the way words that best disclose the direction of thought are highlighted in speech, similar principal carriers of musical thought form in Taneyev's music.

A special distinctive feature of the key intonation of many of Taneyev's significant compositions is their invocatory-interrogative semantics. The brightest examples in this respect are the opening themes of the cantata At the Reading of a Psalm, Symphony in C-Moll and the opera trilogy Oresteia:

Allegro tempestoso. MM.

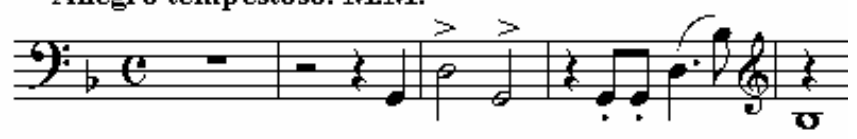

Fig. 1. Cantata "At the Reading of a Psalm

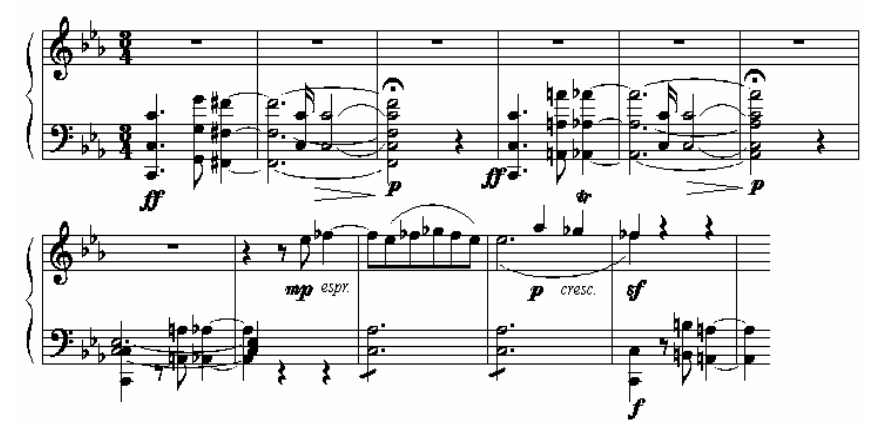

Fig. 2. Symphony in C-Moll

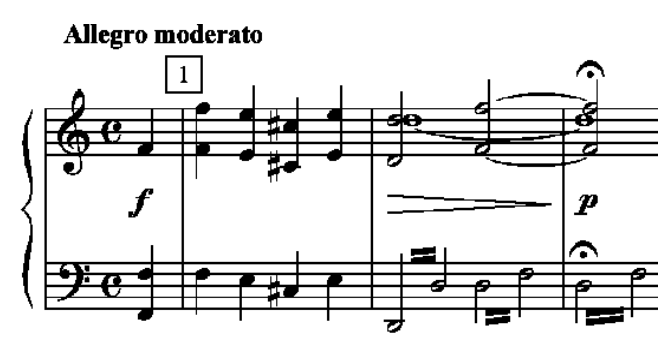

Fig. 3. Opera Oresteia

They implicitly are impelled and filled with energy intonations at their basis that are similar in form. They are laconic, maximally prominent and relatively closed.

The interrogative semantics predetermines the interlocutory form of developing the themes of this kind. The initial functions of 'the participants of the dialogue' in Taneyev's works vary: in the cantata At the Reading of a Psalm the Voice of God appeals to the world piercing the whole human being; in St. John Damascene the soul devotionally calls to God, the key intonation of the symphony suggests an interrogative exclamation of a person with his eyes directed heavenwards, able to communicate with God [2]. In Oresteia, the starting interrogative exclamation renders the ambiguity of the image of the initial intonation, symbolizing the complicated inner life of a person whose perplexed soul is searching for a way out of the fatal circumstances [3]. Taneyev's intonation of interrogation calls on the man to conscious selfdetermination. It reveals the inner dialogue of a person longing to find integrity that can be reached in linking human will and God's will. V. N. Lossky described the essence of such a 'dialogue' in the following way: "God is calling us, and we are filled with this call, and we cannot understand it except in precisely this connection with Him" [4], i.e. in Love.

Thanks to the dialogical principle of development, the listener from the very first bars has the capability to engage in the process of philosophical reflection. Embedded in the initial intonation core and serving as a powerful impulse for this process is the 'polarity': stable - unstable (question call) as two complementary elements; thesis and antithesis.

In the process of gradual unfolding of the intone form of the symphony, cantatas and the opera become the essence of the dialogue and changes from inner conflict to accordance. It is worthy to note that even in developmental parts, where composers most often accentuate the point of confrontation, Taneyev, in his Symphony in C Minor, draws the theme contrapuntally in the first place. In connection with the monothematic method of musical form development, it allows the author to develop the thought on a long breath, with contemplative hastelessness. It's not the principle of contraposition, immanent in dramaturgy of sonata form, that works here, but the principle of 'self-locomotion', 'chain' intergrowth with constant intonation renewal. This principle is less similar to the romantic monothematic technique, but more to the intonation principle of varied anaphora in znamenny chants. The dialogical intonation development of Taneyev's works reveals the light element as the figurative 
and semantic keynote of the concept of his compositions. In the light of the idea of love for one's neighbor (in the cantatas and choral opus to poems by Yakov Polonsky) and the idea of heartful penitence (in Oresteia), such logic of development is identified with the logic of the process of spiritual ascent to the 'inner man'.

Thus the contents of Taneyev's bigger works opens in the light of ideas of Russian religious philosophy. Its fundamental principle, from the origin to I. A. Ilyin and A. F. Losev, is the principle of a religious mind.

Russian philosophy inherently hates the idea of selfdestruction of culture, of the end of the world as 'a completion of an inwardly necessary evolution' predicted by O. Spengler, the demonism of Übermensch suggested by Nietzsche who denied actual human existence, and similar ideas generated by the spirit of fatalism characteristic of European philosophy of the turn of the $20^{\text {th }}$ century. Russian philosophy doesn't cross the borders of its religious field of the New Testament. This is the essence of the philosophy of Taneyev's music as well.

\section{CONCLUSION}

In spite of all the ambiguousness of Taneyev's Christian convictions (as well as of many other representatives of Russian intelligentsia of that time), it is beyond doubt that this musician realized the danger constituted by the influence of the poison of nihilism spreading actively in Russian culture, and of positivism in the world outlook that was indifferent to the truth. Brought up by the whole structure of Russian life, he supposed that turning to the ancient national models 'for advice' could take art out of the dead-lock of 'frigid non-loving' and 'differing'. It reflects a certain inner tune of the composer's muse that determined the national specific character of his thinking. As characterized by $\mathrm{S}$. Frank, the specific character of Russian thinking lies in the fact that it "was never satisfied by the abstract theoretical knowledge, but always strived for a certain religious and ethical worldview that necessarily included the theme of salvation of man and mankind' [5]. The ideal of saving 'sobornost' love proposed in Taneyev's works is the core of Russian Christian philosophy in its initial idea of integral knowledge, that is of the natural completeness of life.

It's characteristic that for his choral works Taneyev chooses poetry by A. S. Khomyakov, A. K. Tolstoy, Ya. P. Polonsky whose leading motive is belief in the invincibility of human spirit. In his letter to Yu. I. Sabaneyeva dated 1897, Taneyev writes that 'without the conscientious and sincere attitude to the spiritual side of his nature, man can become neither moral nor happy' [6]. In his work, Taneyev, like many Russian religious thinkers, brings into focus the theme of the inner man growth in the good, as opposed to the concepts narrowing the phenomenon of man down to power, wanting and having. Taneyev's philosophy of music is addressed to the depth of a human being. Love, concord, harmony, spiritual reconciliation, mercy and divinization are the meanings that fill the symbolism of the idea of perfect organization of existence in Taneyev's musical compositions.
In his creative work, Taneyev is guided by the criteria of reason that remains connected to the Logos - the Source of all truths. For Taneyev, mankind is impossible without the spiritual, the celestial, - without God.

Thus, the fundamental principle of the philosophy of Taneyev's music, as well as of Russian religious philosophy, is the principle of a religious mind. This is the essence of Russian philosophy inheriting the spiritual traditions of the Orthodox Christianity.

\section{REFERENCES}

[1] A. F. Losev, Antique Literature, under the editorship of Prof. A. A. Takho-Godi, textbook for higher school, $7^{\text {th }}$ edition, CheRo, Omega-L, Moscow, 2005, p.

[2] G. U. Aminova, Concept of Sobornost Man in Symphony in C Minor by S. I. Taneyev // Article in the collected volume of materials of the conference 'Problems of Art Interpretation", The Gnesins' Academy of Music, Moscow, 2010, p.208-223.

[3] Lukina G. On Aeschilles Reading: Sergey Taneev's Oresteya Triology // Art Education and Science. Moscow, 2015, p.125-138

[4] V. Lossky. Essays of mystical theology of the Eastern Church.Moscow, 1991, p. 21.

[5] S. Frank Ethical, Philosopho-Juridical and Socio-Philosophical Tendencies in Contemporary Russian Philosophy outside the USSR (1936).

[6] S. I. Taneev Materials and documents. T.1. Correspondence and memoirs. Moscow, 1952, p. 311 